\title{
Penerapan Vector Error Correction Model pada Variabel Makro Ekonomi di Indonesia
}

\author{
Moh. Faizin \\ Ekonomi Syariah, IAIN Ponorogo, Indonesia \\ E-mail: faiziniainpo@gmail.com
}

\begin{abstract}
Abstrak: Negara dapat dikatakan sedang dalam keadan baik perekonomian nasionalnya apabila terdapat beberapa indikator makro ekonomi yang positif, diantaranya inflasi yang turun, jumlah uang yang beredar juga turun, nilai tukar menguat atas mata uang asing serta berkurangnya tingkat suku bunga acuan. Tujuan penelitian ini menganalisis hubungan kausalitas dan kointegrasi dari variabel makro ekonomi, dengan menggunakan data time series tahun 2010-2019 dan menggunakan model VECM. Hasil penelitian didapati bahwa bahwa inflasi dan BI rate tidak terdapat hubungan kausalitas. Begitu pula variabel jumlah uang beredar tidak saling mempengaruhi BI rate. Untuk variabel kurs juga tidak saling berpengaruh terhadap variabel BI rate. Hasil uji kausalitas juga menunjukkan bahwa jumlah uang beredar tidak terdapat hubungan kausalitas terhadap inflasi, Sementara variabel kurs saling berpengaruh terhadap inflasi. kurs tidak saling berpengaruh terhadap variabel jumlah uang yang beredar. Penjelasan hasil estimasi model VECM secara umum menunjukkan adanya hubungan jangka panjang dan hubungan jangka pendek dari masing-masing variabel.
\end{abstract}

Kata kunci: Inflasi, jumlah uang beredar, kurs, suku bunga.

\begin{abstract}
In this time, the countries can be said to be in a good condition of the national economy if there are some indicators in positive economic macro, it is including the decline of inflation, the amount of money circulating is also decline, and the exchange rate strengthening against foreign currencies and reduced interest rates. The purpose of this study is to analyze the causality and cointegration relationships of economic macro variables, by using time series data for 2010-2019 and using the VECM model. The results of the study found that there is no causality relationship between inflation and the BI rate. Likewise, the variable money supply does not affect the BI rate. The exchange rate also does not affect each other on the BI rate variable. Causality test results also indicate that the money supply does not have a causality relationship to inflation, while the exchange rate variables influence each other on inflation. To exchange rates, it does not give affect in the variable amount of money in circulation each other. By explanation of the estimation results of the VECM model, it shows the long-term and short-term relationships of each variable generally.
\end{abstract}

Keywords: Inflation, money supply, exchange rates, interest rates. 


\section{PENDAHULUAN}

Negara dapat dikatakan sedang dalam keadan baik perekonomian nasionalnya apabila terdapat beberapa indikator makro ekonomi yang positif, diantaranya inflasi yang turun, jumlah uang yang beredar juga turun, nilai tukar menguat atas mata uang asing serta berkurangnya tingkat suku bunga acuan. Kebalikan dari keempat indikator tersebut mengindikasikan ekonomi dalam keadaan yang kurang baik (Adisetiawan, 2014).

Inflasi sebagai indikator makro yang pertama merupakan permasalahan di hampir semua negara berkembang dan senantiasa menjadi perhatian pemerintah (Hendajany, 2016). Ketika inflasi terus naik, harga komoditi di masyarakat juga mengalami kenaikan. Hal ini disebabkan akibat jumlah uang yang beredar di masyarakat berlebih. Kenaikan kebutuhan di masyarakat apabila tidak diimbangi dengan kenaikan pendapatan akan mengakibatkan terjadinya penurunan daya beli. Pada sektor riil penurunan daya beli merupakan sinyal negatif bagi kalangan dunia usaha. Hasil produksi akan menumpuk karena tidak laku di pasaran. Akibatnya untuk mengurangi beban perusahan yang disebabkan oleh berkurangnya pendapatan usaha biasanya akan dilakukan perampingan karyawan. Hal ini apabila tidak segera mendapatkan penanganan kebijakan yang tepat akan menjadi siklus yang berat pada perekonomian nasional. Pemerintah mempunyai peran yang besar dalam perencanaa, keputusan atas kebijakan sekaligus evaluasi terhadap kebijakan perekonomian

Nilai inflasi nasional tercermin dari kondisi stabil tidaknya nilai mata uang terhadap barang/komoditi. Disisi yang lain fluktuasi inflasi juga akan berpengaruh pada tingkat kepercayaan para investor dalam pasar keuangan, artinya perkembangan kurs mata uang juga terdampak atas terjadinya fluktuasi inflasi. Nilai tukar atau kurs merupakan ukuran dari suatu valuta terhadap valuta lain. Negara yang mengalami fluktuasi nilai tukar akan sangat mudah terdepresiasi nilai tukar mata uangnya. Kegiatan investasi akan banyak berkurang akibat kondisi ekonomi yang buruk (Kristanto dan Idris, 2016). Pada dunia usaha kurs sangat mempengaruhi tingkat kompetitif perusahaan khususnya pelaku usaha yang mengandalakan bahan baku dari impor. Hal ini diakibatkan oleh naiknya beban produksi/biaya operasional perusahaan (Viska dan Yusra, 2019). Sebagai dampak perdagangan internasional, nilai mata uang suatu negara menjadi sangat bdiperhitungkan. Selain meningkatnya pasar yang menjadi peluang para pengusha, juga menjadikan konsumen menjadi banyak pilihan atas produk yang ingin ia gunakan (Noviantoro, 2017). Indonesia saat ini menganut sistem tukar mata uang yang mengambang, artinya pasar keuangan bergerak atas terjadinya permintaan/penawaran itu sendiri. Sistem tukar seperti ini akan menimbulkan potensi terjadinya fluktuasi nilai tukar yang berdampak pada situasi yang tidak pasti dalam iklim dunia usaha.

Indikator variabel makro yang ketiga adalah tingkat suku bunga. Selain sangat berpengaruh terhadap stabilnya inflasi, suku bunga juga dianggap sebagai faktor yang juga berpengaruh terhadap nilai tukar (Desvina dan Lubis, 2019). Kebijakan moneter untuk mengendalikan suku bunga bank sentral merupakan upaya dalam menjaga stabilitas moneter dalam negeri. Suku bunga yang berubah akan berdampak pada modal dan pasar keuangan (Zaimsyah dkk., 2020). Naiknya suku bunga akan mengakibatkan investor mengalihkan mekanisme investasinya dari sektor pasar modal ke sektor perbankan melalui deposito (Andiantyo dkk., 2018). Pendapat senada juga disampaikan (Nisa dan Sukmana, 2017), dampak kenaikan suku bunga akan mengakibatkan menurunnya harga saham. Ketika 
suku bunga dinaikkan beban bunga otomatis naik (Triyono dkk., 2016). Ketika suku bunga diturunkan, akan berpengaruh terhadap bergairahnya dunia usaha. Artinya para investor akan mengalihkan instrument investasinya pada sektor riil, karena tidak sekedar menyimpan uangnya di bank. Berbeda bagi para pengusaha, kenaikan suku bunga akan menjadi kabar buruk dalam kegiatan usahanya, hal ini disebabkan karena naiknya suku bunga pasti akan diikuti naiknya bunga pinjaman perbankaan, artinya beban usaha akan semakin besar (Najiatun dkk., 2019). Inflasi dan suku bunga juga dapat menimbulkan dampak pada laju inflasi relatif negara lain. Akibatnya nilai valuta juga menurun akibat dari ekspor yang juga menurun. Walaupun demikian, inflasi tidak selamanya menjadi ancaman yang mengerikan bagi perekonomian, laju inflasi yang tekendali dapat memicu meningkatnya perekonomian akibat bergairahnya dunia usaha.

Variabel makro ekonomi selanjutnya adalah jumlah uang beredar. Kebijakan moneter dalam perekonomian diharapkan mampu untuk mempengaruhi variabel makro ekonomi yang mana sasaran akhir dari kebijakan tersebut adalah dapat mempengaruhi harga dan kegiatan usaha di sektor riil (Natsir, 2018). Kenaikan kuantitas atas uang yang beredar akan mengakibatkan laju inflasi tak terkendali. Akibatnya bank sentral akan berupaya menjaga stabilitas moneter dengan menaikkan suku bunga acuan. Pemerintah dalam hal ini dituntut untuk mampu membuat perkiraan kondisi makro ekonomi untuk periode yang akan datang dengan berdasarkan asumsi dan kondisi makro ekonomi saat ini.

Telah banyak penelitian terdahulu yang membahas terkait variabel makro ekonomi, tetapi sering kali menunjukkan hasil yang berbeda dan cenderung tidak konsisten. Penelitian yang dilakukan (Janah \& Pujiati, 2018), penelitian (Ratih dkk., 2019) menunjukkan bahwa terdapat hubungan kausalitas variabel inflasi dan kurs. Begitu pula BI rate berpengaruh terhadap inflasi baik jangka pendek maupun jangka panjang. Penelitian (Luwihadi \& Arka, 2017) menghasilkan bahwa uang beredar dipengaruhi suku bunga secara negatif dan signifikan, serta mempunyai pengaruh positif terhadap inflasi. Sementara uang beredar tidak berpengaruh terhadap inflasi, serta kurs tidak berpengaruh terhadap inflasi. Sementara penelitian (Nofiatin, 2013) menyebutkan bahwa hubungan kointegrasi terjadi antara inflasi, suku bunga dan nilai tukar. Serta terjadi hubungan kausalitas antara inflasi terhadap suku bunga, jumlah uang beredar terhadap suku bunga. Berangkat dari latar belakang tersebut diatas maka penelitian ini mengambil tema penerapan model VECM pada variabel kurs, suku bunga dan uang beredar terhadap inflasi di Indonesia.

\section{KAJIAN TEORI}

Inflasi. Inflasi didefinisikan sebagai sebuah fenomena naiknya harga komoditi yang berlangsung secara terus menerus akibat tidak adanya keseimbangan antara suplay dan demand di tengah masyarakat. Kenaikan atas sebagian barang saja dan terjadi hanya dalam waktu sebentar yang diakibatnya naiknya permintaan atas barang dan jasa menjelang hari besar tententu tidak dikategorikan sebagai inflasi. Inflasi sendiri selain memiliki gejala atas kenaikan harga, pada prinsipnya merupakan keadaan menurunnya nilai sebuah mata uang tertentu terhadap harga relatif atas barang dan jasa. (Mankiw, 2007) menjelaskan bahwa diantara penyebab terjadinya inflasi selain disebabkan naiknya permintaan, juga disebabkan oleh terhambatnya jalur distribusi, bencana alam, serta naiknya biaya produksi. 
Kurs. Kurs merupakan sejumlah harga yang harus dikeluarkan untuk mendapatkan satu satuan mata uang asing (Salvatore, 2014). Nilai tukar mata uang tidak selalu konstan sehingga setiap waktu terus mengalami fluktuasi. Hal ini yang menyebabkan kurs atau nilai tukar mata uang menjadi salah satu faktor makro ekonomi yang teramat penting. Mengingat dampak atas fluktuasi yang terjadi terhadap nilai mata uang akan berpengaruh terhadap kegiatan ekonomi internasional suatu negara. Tidak ahanya terkait perdagangan ekspor dan impor tetapi terkait juga dengan masalah pinjaman/utang luar negeri. Saat mata uang dalam negeri mengalami kenaikan (apresiasi) ini akan menjadi sinyal positif bagi kegiatan perekonomian, sebaliknya saat terjadi depresiasi akan menjadi pertanda buruk.

Jumlah uang beredar (JUB). (Sukirno, 2004) menjelaskan bahwa jenis uang beredar terbagi menjadi dua. Pertam uang beredar dalam arti sempit. Uang dalam arti sempit terdiri dari uang yang dipegang oleh masyarakat (M1), kedua, uang dalam arti luas. Uang dalam arti luas didefinisikan sebagai uang yang dipegang masyarakat ditambah dengan uang giral yang berada di bank.

BI rate. Sejak pertengahan 2016 kebijakan atas suku bunga yang berlaku di Indonesia menggunakan istilah BI 7-Day repo rate. Instrumen kebijakan ini dikeluarkan oleh bank Indonesia dengan maksud untuk mempengaruhi pasar keuangan. Karena bersifat transaksional BI rate mempunyai keterkaitan yang erat dengan suku bunga di pasaran. Suku bunga merupakan nilai yang harus dibayar seseorang yang disebabkan karena pinjaman untuk jangka waktu tertentu (Sunariyah, 2011). Dalam bahasa yang berbeda suku bunga merupakan pendapatan bagi seorang kreditor dan sebuah beban bagi seorang debitor.

\section{Kerangka Pemikiran}

Kerangka pemikiran penelitian ini dijelaskan pada Gambar 1.

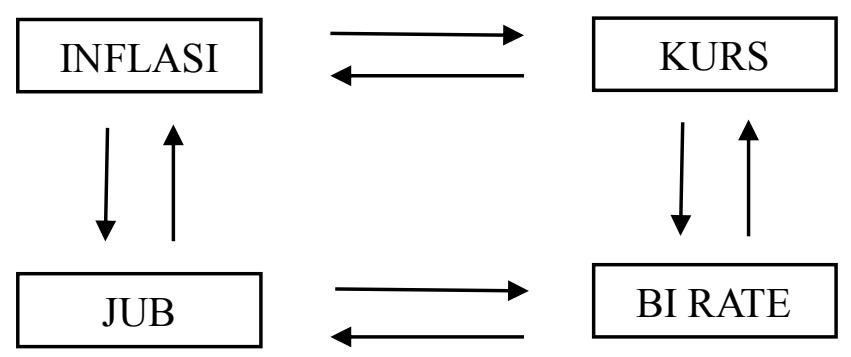

Gambar 1. Kerangka Pemikiran

\section{Hipotesis}

(a) $\mathrm{H}_{\mathrm{a}} 1$ : diduga terdapat kausalitas antara variabel inflasi, kurs, jumlah uang beredar dan $\mathrm{BI}$ rate

(b) $\mathrm{H}_{\mathrm{a}} 2$ : diduga terdapat kointegrasi antara variabel inflasi, kurs, jumlah uang beredar dan $\mathrm{BI}$ rate 


\section{METODE}

Penelitian ini menggunakan model VECM dalam menganalisis data sekunder berjenis data time series untuk periode pengamatan Januari 2010 - Desember 2019. Analisis time series digunakan dalam pengamatan data yang disajikan dari waktu kewaktu, dimana selain terpengaruh variabel lain, variabel tersebut juga terpengaruh oleh nilai variabel untuk periode sebelumnya (Ekananda, 2016). Jenis data yang digunakan terdiri dari data laporan bulanan inflasi, kurs rupiah-dolar, suku bunga BI dan jumlah uang beredar di Indonesia. Model VECM dianggap paling tepat dalam penelitian yang menggunakan data time series multivariate (Widokartiko dkk., 2016), hal ini dikarenakan pada model adalah memperkirakan hubungan jangka pendek/panjang variabel yang satu dengan variabel yang lain dengan menggunakan data runtut waktu untuk setiap variabel tersebut.Tahapan dalam menganalisis dengan menggunakan model VECM terdiri dari:

Stasioneritas. Penggunaan data berjenis time series memerlukan pengujian di awal dari data untuk setiap variabel. Tujuan dari uji stasioner ini adalah untuk memastikan bahwa data mengalami fluktuasi pada kisaran rerata dan konstan. Uji ini menggunakan uji unit root ADF. Hasil uji unit root bisa dikatakann telah stasioner apabila nilai probabilitas $(<0,05)$. Apabila pengujian data level belum ditemukan hasil yang stasioner maka akan dilakukan pengujian kedua pada kondisi data first different.

Lag Optimal. Tahap selanjutnya setelah dilakukan uji unit root maka dilakukan pemeriksaan lag optimal. Seperti halnya dalam penggunaan model VAR, pengukuran lag optimal bertujuan untuk memastikan bahwa model dapat menjelaskan secara dinamis dan menyeluruh dan efisien. Dalam menentukan lag optimal tidak boleh terlalu pendek atau terlalu panjang. Panjang lag yang terlalu pendek berdampak pada ketidakmampuan model dalam menjelaskan dinamisasi model dengan menyeluruh. Sebaliknya lag yang terlalu panjang menjadikan pengukuran model menjadi tidak efisien.

Uji Stabilitas. Setelah dilakukan uji unit root dan uji lag optimal maka tahap selanjutnya dilakukan uji stabilitas. Hal ini diperlukan agar nantinya tahap peramalan dengan menggunakan IRF dan VD dapat dilakukan.

Uji Kointegrasi. Tahap berikutnya yakni uji kointegrasi. Pengujian ini untuk melihat apakah dari masing-masing variabel terjadi keseimbangan dalam jangka panjang.

Uji Kausalitas. Uji kausalitas bertujuan untuk melihat apakah dari variabel endogen juga dapat berperan menjadi variabel eksogen. Berangkat dari asumsi ketidaktahuan apakah variabel yang satu mempengaruhi variabel yang lain, apakah kedua variabel saling berpengaruh atau malah saling tidak mempengaruhi.

Regresi Model VECM. Pengembangan dari model VAR adalah model VECM. Dimana dari data time series masing-masing variabel terdapat hubungan/ kointegrasi. Pada model VECM dapat diketahui dengan mudah baik dari komoponen jangka panjang ataupun pendek (Sulistiana, 2017). 
IRF dan VD. IRF bertujuan untuk mengetahui seperti apa laju dari shock yang terjadi pada salah satu variabel dan pengaruhnya pada variabel yang lain (Lubis, 2017). Tidak hanya melihat efek shock/guncangan variabel dengan menggunakan uji IRF kita dapat mengetahui sampai kapan pengaruh shock itu akan hilang sampai titik keseimbangan kembali pulih. Selain dengan menggunakan IRF dalam model VECM juga terdapat Variance Decomposition (VD). VD digunakan untuk menjelaskan besaran dan lama proporsi goncangan dari sebuah variabel terhadap variabel itu sendiri sekaligus proporsi terhadap variabel yang lain.

\section{HASIL DAN PEMBAHASAN}

Stasioneritas. Uji stasioner merupakan tahap awal dalam penggunaan model VAR atau VECM. Penerapan uji stasioneritas dapat dilihat pada Tabel 1. Pada Tabel 1 diketahui bahwa uji unit root didapati bahwa nilai probabilitas pada data level belum stasioner, sehingga perlu dilakukan pengujian tahap kedua dengan first different. Data yang tidak stasioner berarti data tersebut mengandung unit root, sedangkan data yang stasioner berarti data tersebut tidak mengandung unit root artinya data tersebut mendekati rata-rata dan tidak terpengaruh waktu. Pada kondisi first different keempat variabel menunjukkan nilai probabilitas dibawah 5\% sehingga data bisa dilanjutkan untuk proses selanjutnya. Pada model VAR dan VECM mutlak diperlukan data yang stasioner, hal ini untuk memastikan hasil pada regresi tidak menunjukkan keterkaitan antar variabel yang terlihat signifikan pada model statistik tetapi pada kenyataannya malah berbeda.

Tabel 1. Hasil Uji Unit root

\begin{tabular}{lcccc}
\hline \hline \multicolumn{4}{c}{ Augmented Dickey-Fuller test statistic } \\
\hline \multirow{2}{*}{ Variabel } & \multicolumn{2}{c}{ Level } & \multicolumn{2}{c}{ first different } \\
\cline { 2 - 5 } & t-Statistic & Prob. ${ }^{*}$ & t-Statistic & Prob.* \\
\hline INFLASI & -2.426 .290 & 0.1368 & -8.168 .852 & 0.0000 \\
KURS & -0.730105 & 0.8341 & -8.546 .604 & 0.0000 \\
JUB & 0.082990 & 0.9632 & -1.295 .383 & 0.0000 \\
BIRATE & -1.326 .565 & 0.6155 & -7.098 .365 & 0.0000 \\
\hline
\end{tabular}

Sumber: data skunder diolah

Uji Lag Optimal. Setelah data stasioner tahap adalah mencari lag optimal dengan menggunakan Lag Order Selection Criteria. Hasilnya dapat dilihat pada Tabel 2. Pada Tabel 2 menunjukkan bahwa kondisi lag optimal berada pada lag 1. Kondisi lag optimal dapat diketahui dengan melihat banyaknya tanda bintang pada masing-masing kriteria yang terdapat pada tabel. Dalam menentukan pemilihan lag/kelambanan diperlukan dalam penerapan model untuk melihat hubungan serta perilaku pada masing-masing variabel yang ada pada sistem. Pemilihan lag yang kecil terlalu kecil akan berdampak pada ketidakmampuan model dalam mengintepretasikan hungan antar variabel. Sementara penetapan lag yang terlalu besar berdampak pada ketidakefisienan penjelasan model 
Tabel 2. Hasil Uji Lag Optimal

\begin{tabular}{ccccccc}
\hline \hline Lag & LogL & LR & FPE & AIC & SC & HQ \\
\hline \hline 0 & -2717.442 & NA & $2.32 \mathrm{e}+16$ & 49.03499 & $49.13263^{*}$ & $49.07460^{*}$ \\
1 & -2694.119 & $44.54563^{*}$ & $2.03 \mathrm{e}+16^{*}$ & $48.90304^{*}$ & 49.39124 & 49.10109 \\
2 & -2681.790 & 22.65816 & $2.18 \mathrm{e}+16$ & 48.96919 & 49.84795 & 49.32568 \\
3 & -2677.754 & 7.125597 & $2.71 \mathrm{e}+16$ & 49.18476 & 50.45409 & 49.69969 \\
4 & -2672.235 & 9.348894 & $3.29 \mathrm{e}+16$ & 49.37360 & 51.03349 & 50.04697 \\
5 & -2666.002 & 10.10617 & $3.96 \mathrm{e}+16$ & 49.54959 & 51.60005 & 50.38140 \\
6 & -2650.782 & 23.58530 & $4.06 \mathrm{e}+16$ & 49.56364 & 52.00465 & 50.55388 \\
7 & -2643.056 & 11.41415 & $4.80 \mathrm{e}+16$ & 49.71273 & 52.54431 & 50.86142 \\
8 & -2630.559 & 17.56407 & $5.24 \mathrm{e}+16$ & 49.77583 & 52.99798 & 51.08296 \\
\hline \hline
\end{tabular}

Uji Stabilitas. Tahap berikutnya dengan menggunakan uji stabilitas. Uji stabilitas ini berfungsi untuk memastikan bahwa dalam model VECM dapat dilakukan peramalan dengan menggunakan IRF dan VD. Selain itu, penggunaan model yang tidak stabil akan mengakibatkan hasil estimasi menjadi kurang valid. Hasil dari uji stabilitas dapat dilihat pada Tabel 3. Hasil uji stabilitas dengan kondisi firstdifferent lag 1 diketahui bhwa model VAR sudah stabil, hal ini dapat diketahui dengan melihat nilai keseluruhan dari modulus kurang dari 1, tidak ada yang melebihi 1 .

Tabel 3. Hasil Uji Stabilitas

\begin{tabular}{rr}
\hline \hline Root & Modulus \\
\hline \hline 0.460104 & 0.460104 \\
0.238118 & 0.238118 \\
-0.193893 & 0.193893 \\
0.110573 & 0.110573 \\
\hline \hline
\end{tabular}

Uji Kointegrasi. Uji kointegrasi diperlakukan untuk menentukan penggunaan model, memilih menggunakan model VAR atau model VECM. Pengujian ini dilakukan untuk melihat adanya keseimbangan jangka panjang berupa pergerakan yang sama serta hubungan antar variabel yang stabil. Dengan menggunakan uji JCT, didapat hasil pengujian pada Tabel 4. diketahui bahwa nilai probabilitas kurang dari 5\%, hal ini dapat diartikan bahwa terdapat kointegrasi antar variabel. Dari hasil uji kointegrasi maka analisis model VECM dapat dilanjutkan.

Tabel 4. Hasil Uji Kointegrasi

\begin{tabular}{ccccc}
\hline \hline $\begin{array}{c}\text { Hypothesized } \\
\text { No. of CE(s) }\end{array}$ & Eigenvalue & $\begin{array}{c}\text { Trace } \\
\text { Statistic }\end{array}$ & $\begin{array}{c}\mathbf{0 . 0 5} \\
\text { Critical Value }\end{array}$ & Prob. $^{* *}$ \\
\hline \hline None $*$ & 0.445905 & 197.1464 & 47.85613 & 0.0000 \\
At most $1 *$ & 0.419725 & 128.0673 & 29.79707 & 0.0000 \\
At most 2* & 0.317294 & 64.38969 & 15.49471 & 0.0000 \\
At most 3* & 0.155194 & 19.73179 & 3.841466 & 0.0000 \\
\hline
\end{tabular}


Uji Kausalitas. Dengan melihat hasil uji kausalitas pada Tabel 5, apabila nilai prob. $<0,05$ maka disimpulkan terjadi kausalitas, tetapi apabila nilai prob. $>0,05$ maka disimpulkan tidak terjadi kausalitas pada variabel tersebut.

Tabel 5. Hasil Uji Kausalitas

\begin{tabular}{|c|c|c|c|}
\hline Null Hypothesis: & Obs & F-Statistic & Prob. \\
\hline $\begin{array}{l}\text { INFLASI does not Granger Cause BIRATE } \\
\text { BIRATE does not Granger Cause INFLASI }\end{array}$ & 119 & $\begin{array}{l}16.7254 \\
0.00029\end{array}$ & $\begin{array}{l}8 . \mathrm{E}-05 \\
0.9864\end{array}$ \\
\hline $\begin{array}{l}\text { JUB does not Granger Cause BIRATE } \\
\text { BIRATE does not Granger Cause JUB }\end{array}$ & 119 & $\begin{array}{l}1.17979 \\
0.01687\end{array}$ & $\begin{array}{l}0.2797 \\
0.8969\end{array}$ \\
\hline $\begin{array}{l}\text { KURS does not Granger Cause BIRATE } \\
\text { BIRATE does not Granger Cause KURS }\end{array}$ & 119 & $\begin{array}{l}1.38840 \\
0.41293\end{array}$ & $\begin{array}{l}0.2411 \\
0.5218\end{array}$ \\
\hline $\begin{array}{l}\text { JUB does not Granger Cause INFLASI } \\
\text { INFLASI does not Granger Cause JUB }\end{array}$ & 119 & $\begin{array}{l}3.84755 \\
0.03178\end{array}$ & $\begin{array}{l}0.0522 \\
0.8588\end{array}$ \\
\hline $\begin{array}{l}\text { KURS does not Granger Cause INFLASI } \\
\text { INFLASI does not Granger Cause KURS }\end{array}$ & 119 & $\begin{array}{l}4.31649 \\
6.13995\end{array}$ & $\begin{array}{l}0.0400 \\
0.0147\end{array}$ \\
\hline $\begin{array}{l}\text { KURS does not Granger Cause JUB } \\
\text { JUB does not Granger Cause KURS }\end{array}$ & 119 & $\begin{array}{l}0.10745 \\
2.09412\end{array}$ & $\begin{array}{l}0.7437 \\
0.1506\end{array}$ \\
\hline
\end{tabular}

Hasil uji kausalitas yang tersaji pada Tabel 5 diketahui bahwa inflasi berpengaruh terhadap BI rate, begitu pula BI rate juga berpengaruh terhadap inflasi, sementara variabel jumlah uang beredar tidak terdapat pengaruh terhadap BI rate (karena nilai probabilitas $>0,05)$, serta $B I$ rate tidak berpengaruh terhadap jumlah uang beredar. Untuk variabel kurs juga tidak berpengaruh terhadap variabel $B I$ rate, begitu pula $B I$ rate juga tidak mempengaruhi kurs. Hasil uji kausalitas juga menunjukkan bahwa jumlah uang beredar tidak berpengaruh terhadap inflasi, variabel inflasi juga tidak berpengaruh terhadap uang beredar. Sementara variabel kurs berpengaruh terhadap inflasi, demikian pula inflasi juga berpengaruh terhadap kurs. Hasil ini juga menunjukkan bahwa untuk variabel kurs tidak berpengaruh terhadap variabel jumlah uang yang beredar, serta jumlah uang beredar juga tidak berpengaruh kurs. Hasil ini sejalan dengan penelitian yang dilakukan (Janah \& Pujiati, 2018), berbeda dengan (Luwihadi \& Arka, 2017), (Nofiatin, 2013). Sementara penelitian yang dilakukan (Rasbin, 2016) menunjukkan bahwa ada hubungan jangka pendek antara kurs terhadap uang beredar, serta jumlah uang beredar berpengaruh terhadap tingkat suku bunga. 


\section{Regresi Model VECM}

Tabel 6. Vector Error Correction Estimates

\begin{tabular}{|c|c|c|c|c|}
\hline Cointegrating Eq: & CointEq1 & & & \\
\hline D(INFLASI(-1)) & 1.000000 & & & \\
\hline $\mathrm{D}(\operatorname{KURS}(-1))$ & $\begin{array}{r}-0.001975 \\
(0.00057) \\
{[-3.46676]}\end{array}$ & & & \\
\hline $\mathrm{D}(\mathrm{JUB}(-1))$ & $\begin{array}{c}-1.50 \mathrm{E}-07 \\
(2.2 \mathrm{E}-08) \\
{[-6.75225]}\end{array}$ & & & \\
\hline D(BIRATE(-1)) & $\begin{array}{c}0.236141 \\
(0.58034) \\
{[0.40690]}\end{array}$ & & & \\
\hline $\mathrm{C}$ & 0.604847 & & & \\
\hline Error Correction: & D(INFLASI,2) & D(KURS,2) & $\mathrm{D}(\mathrm{JUB}, 2)$ & D(BIRATE,2) \\
\hline CointEq1 & $\begin{array}{r}-0.251173 \\
(0.07502) \\
{[-3.34788]}\end{array}$ & $\begin{array}{c}122.3125 \\
(25.5141) \\
{[4.79391]}\end{array}$ & $\begin{array}{c}5066731 . \\
(795908 .) \\
{[6.36597]}\end{array}$ & $\begin{array}{c}0.010620 \\
(0.02128) \\
{[0.49911]}\end{array}$ \\
\hline D(INFLASI(-1),2) & $\begin{array}{r}-0.073418 \\
(0.09817) \\
{[-0.74783]}\end{array}$ & $\begin{array}{r}-49.87162 \\
(33.3868) \\
{[-1.49375]}\end{array}$ & $\begin{array}{c}-2328418 \\
(1041496) \\
{[-2.23565]}\end{array}$ & $\begin{array}{c}0.034212 \\
(0.02784) \\
{[1.22877]}\end{array}$ \\
\hline $\mathrm{D}(\mathrm{KURS}(-1), 2)$ & $\begin{array}{r}-0.000314 \\
(0.00025) \\
{[-1.25758]}\end{array}$ & $\begin{array}{r}-0.247613 \\
(0.08497) \\
{[-2.91403]}\end{array}$ & $\begin{array}{c}6794.577 \\
(2650.71) \\
{[2.56331]}\end{array}$ & $\begin{array}{c}2.19 \mathrm{E}-06 \\
(7.1 \mathrm{E}-05) \\
{[0.03093]}\end{array}$ \\
\hline $\mathrm{D}(\mathrm{JUB}(-1), 2)$ & $\begin{array}{c}-2.11 \mathrm{E}-08 \\
(8.6 \mathrm{E}-09) \\
{[-2.44808]}\end{array}$ & $\begin{array}{c}8.90 \mathrm{E}-06 \\
(2.9 \mathrm{E}-06) \\
{[3.03181]}\end{array}$ & $\begin{array}{r}-0.182342 \\
(0.09153) \\
{[-1.99217]}\end{array}$ & $\begin{array}{c}3.30 \mathrm{E}-09 \\
(2.4 \mathrm{E}-09) \\
{[1.34676]}\end{array}$ \\
\hline D(BIRATE(-1),2) & $\begin{array}{c}0.089596 \\
(0.29737) \\
{[0.30129]}\end{array}$ & $\begin{array}{c}53.79909 \\
(101.130) \\
{[0.53198]}\end{array}$ & $\begin{array}{c}2916344 . \\
(3154725) \\
{[0.92444]}\end{array}$ & $\begin{array}{r}-0.428312 \\
(0.08434) \\
{[-5.07862]}\end{array}$ \\
\hline $\mathrm{C}$ & $\begin{array}{c}0.000424 \\
(0.06197) \\
{[0.00684]}\end{array}$ & $\begin{array}{c}0.687735 \\
(21.0735) \\
{[0.03263]}\end{array}$ & $\begin{array}{c}56071.67 \\
(657386 .) \\
{[0.08529]}\end{array}$ & $\begin{array}{c}6.13 \mathrm{E}-05 \\
(0.01757) \\
{[0.00349]}\end{array}$ \\
\hline R-squared & 0.137073 & 0.282613 & 0.499512 & 0.217381 \\
\hline Adj. R-squared & 0.098203 & 0.250298 & 0.476967 & 0.182128 \\
\hline Sum sq. resids & 49.86742 & 5767303. & $5.61 \mathrm{E}+15$ & 4.010921 \\
\hline S.E. equation & 0.670266 & 227.9423 & 7110620. & 0.190091 \\
\hline F-statistic & 3.526403 & 8.745625 & 22.15669 & 6.166306 \\
\hline Log likelihood & -116.1267 & -798.1400 & -2008.857 & 31.31365 \\
\hline Akaike AIC & 2.087635 & 13.74598 & 34.44200 & -0.432712 \\
\hline
\end{tabular}




\begin{tabular}{crrrr} 
Schwarz SC & 2.229285 & 13.88763 & 34.58365 & -0.291062 \\
Mean dependent & 0.000855 & 1.053077 & 53096.58 & 0.000000 \\
S.D. dependent & 0.705818 & 263.2574 & 9832027. & 0.210193 \\
\hline
\end{tabular}

Hasil regresi model VECM dapat dilihat pada Tabel 6. Penjelasan hasil estimasi model VECM secara umum terdiri dari dua bagian tabel, bagian atas menunjukkan hubungan jangka panjang, sementara pada bagian bawah menunjukkan hubungan jangka pendek. Pada bagian atas, diketahui bahwa untuk variabel kurs dan jumlah uang beredar mempunyai pengaruh signifikan terhadap inflasi. Sementara variabel BI rate tidak signifikan, artinya tidak terdapat pengaruh terhadap inflasi. Hal ini ditunjukkan dengan hasil estimasi masing masing kurs sebesar -3.46676, jumlah uang beredar sebesar -6.75225, sementara BI rate hanya menunjukkan angka sebesar 0.40690 . terkait penjelasn mengenai koefisien masing-masing variabel, variabel kurs sebesar -0,001975 artinya setiap kenaikan $1 \%$ dari kurs akan mempengaruhi inflasi sebesar negatif $0,001975 \%$, begitu pula dengan variabel jumlah uang yang beredar, dimana koefisen menunjukkan angka $-1,50$, artinya setiap kenaikan $1 \%$ jumlah uang yang beredar akan berpengaruh pada penurunan inflasi sebesar $1,50 \%$. Sementara variabel BI rate tidak signifikan.

Penjelasan berikutnya merujuk pada bagian bawah Tabel 6. Pada bagian bawah menunjukkan hubungan jangka pendek. Diketahui bahwa hanya variabel jumlah uang beredar yang mempunyai pengaruh jangka pendek terhadap inflasi. Sementara variabel kurs, dan BI rate tidak terdapat pengaruh jangka pendek terhdap inflasi. Dari Tabel 6 juga dapat diketahui besarnya nilai $R$-squar pada masing-masing variabel. Diketahui bahwa nilai terbesar $R$-squar terdapat pada variabel jumlah uang beredar yakni sebesar 0,499512.

IRF dan VD. Penjelasan terkait Gambar 1A-D menunjukkan bagaimana suatu variabel memberikan respon atas goncangan yang terjadi pada variabel itu sendiri maupun variabel yang lain. Analisis yang dihasilkan tidak hanya terkait analisis jangka pendek (awal periode) tetapi juga analisis jangka panjang. Pada gambar 1 terdapat gambar sumbu horizontal, yang menjelaskan waktu serta sumbu vertikal yang menunjukkan nilai/besar respon akibat shok atau goncangan variabel tersebut.

Penjelasan berikutnya adalah terkait Variance Decomposition (VD). Hasil analisis VD dapat diketahui bahwa terdapat kontribusi variabel terhadap variabel itu sendiri sekaligus kontribusi variabel yang lain terhadap variabel tersebut pada periode 1 sampai dengan periode 10 . 

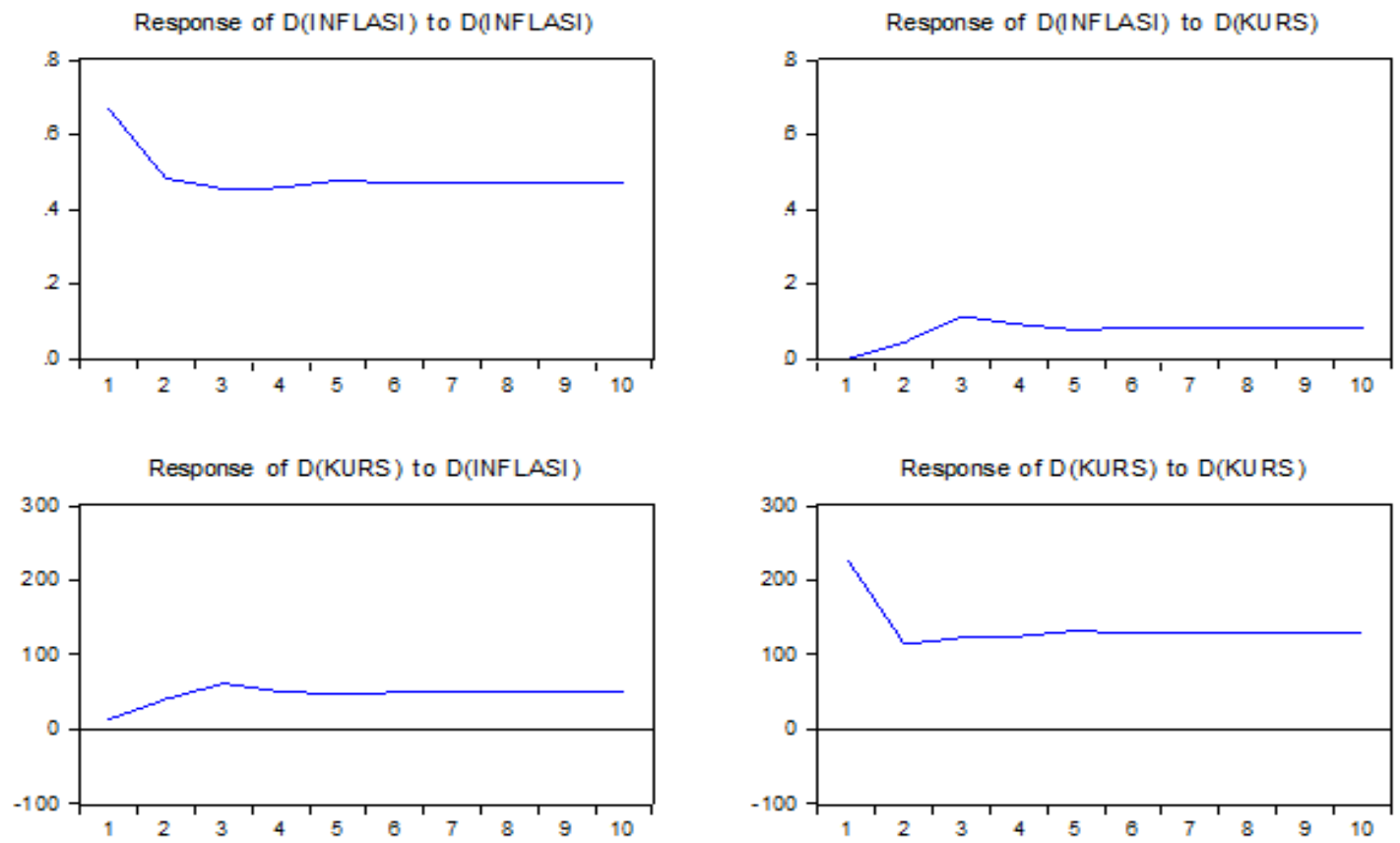

Gambar 1.A Hasil IRF (Impuls Respon Function)
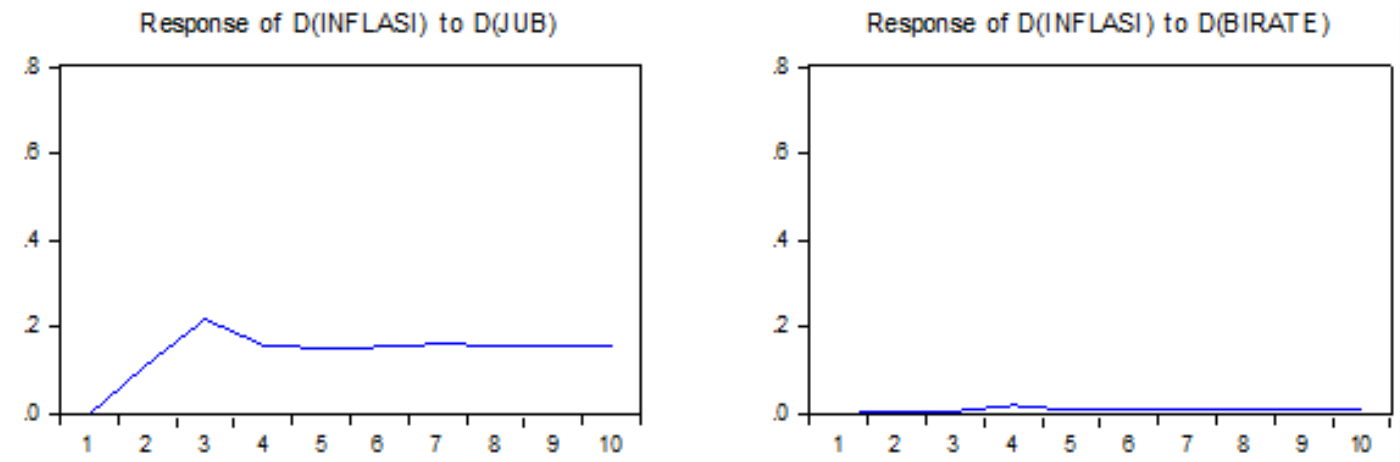

Response of $D$ (KURS) to $D(J U B)$

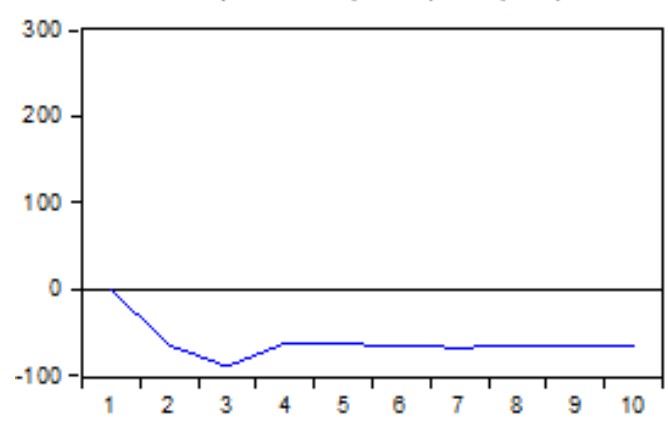

Response of D(KURS) to D(BIRATE)

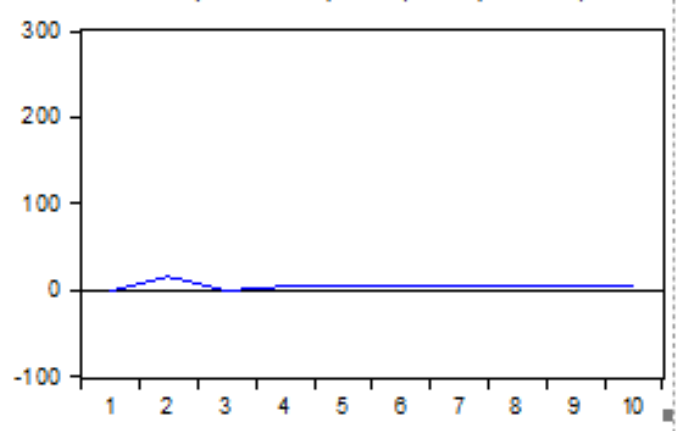

Gambar 1.B Hasil IRF (Impuls Respon Function) 

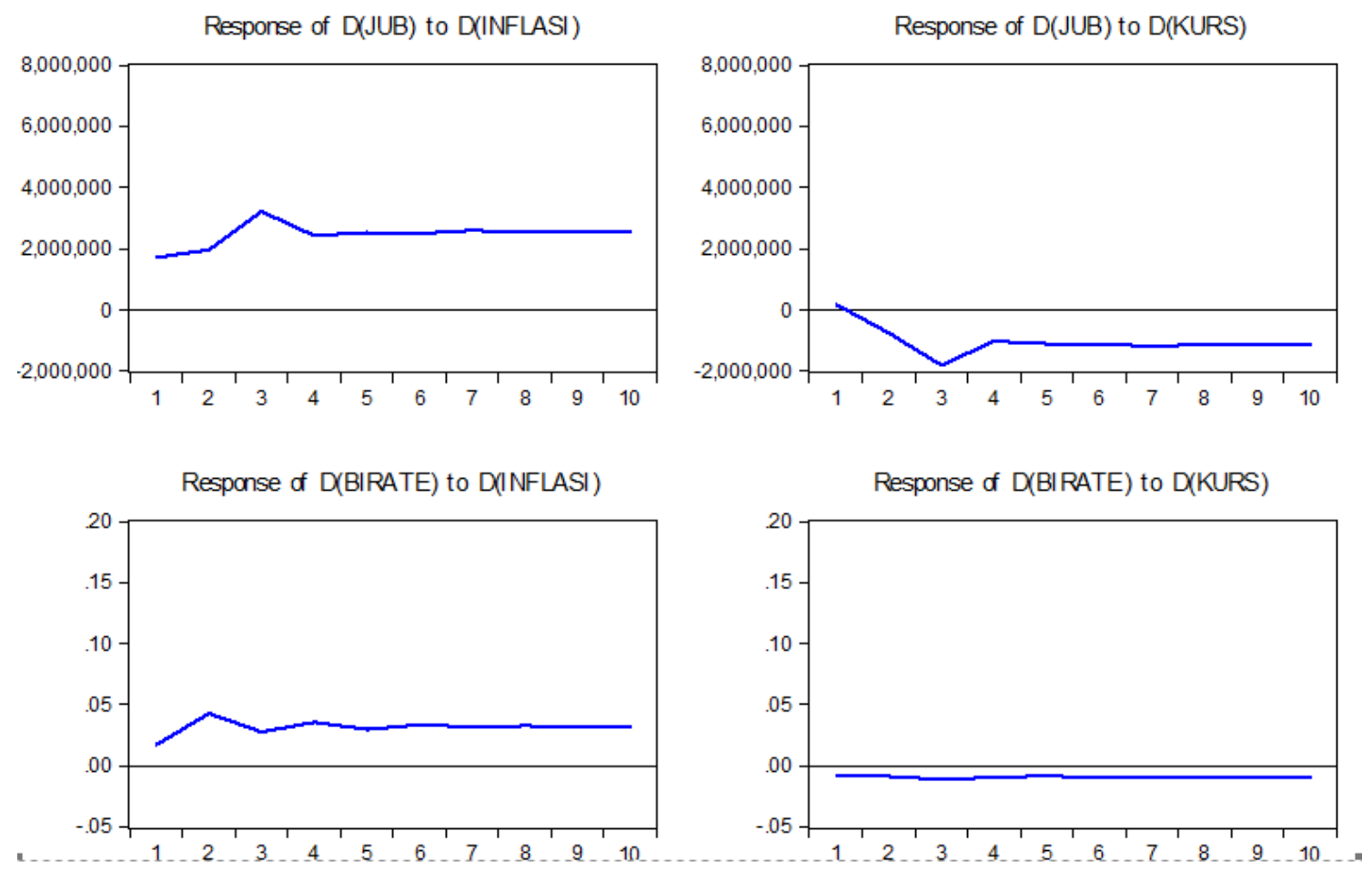

Gambar 1.C Hasil IRF (Impuls Respon Function)

Response of $\mathrm{D}(\mathrm{JUB})$ to $\mathrm{D}(\mathrm{JUB})$

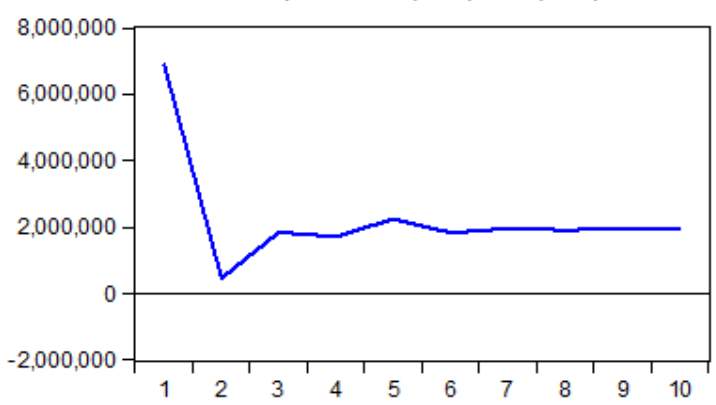

Response of D(BIRATE) to D(JUB)

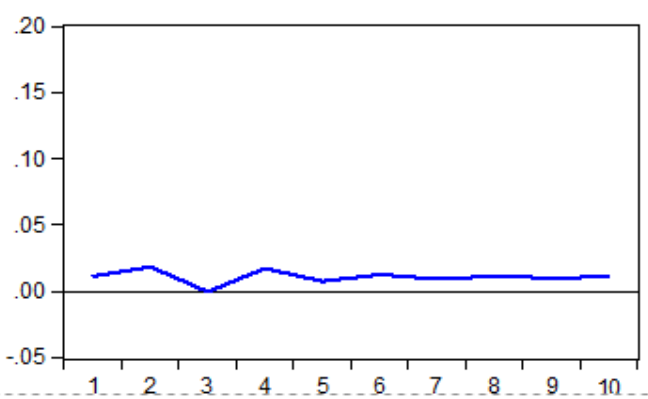

Response of D(JUB) to D(BIRATE)

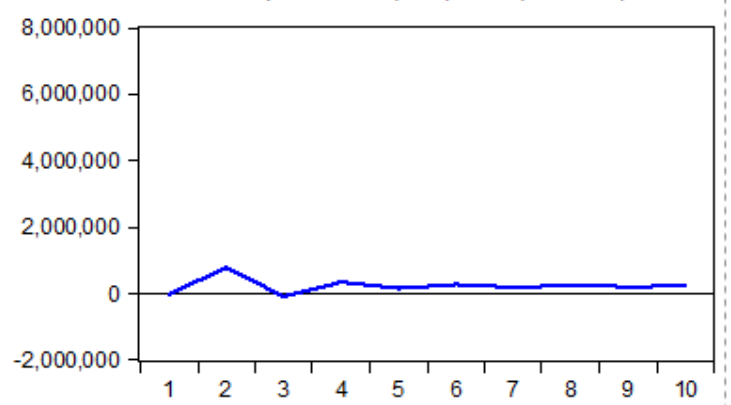

Response of D(BIRATE) to D(BIRATE)

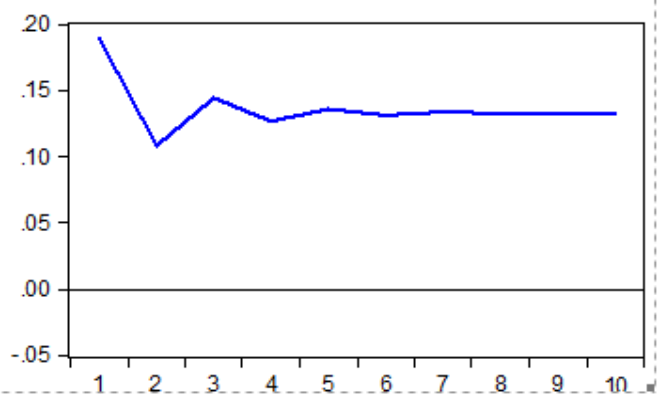

Gambar 1.D Hasil IRF (Impuls Respon Function) 
Tabel 7. Variance Decomposition of D (INFLASI)

\begin{tabular}{cccccc} 
Period & S.E. & D(INFLASI) & D(KURS) & D(JUB) & D(BIRATE) \\
\hline \hline 1 & 0.670266 & 100.0000 & 0.000000 & 0.000000 & 0.000000 \\
2 & 0.835710 & 97.85865 & 0.278827 & 1.857838 & 0.004680 \\
3 & 0.983347 & 92.19049 & 1.543451 & 6.259140 & 0.006921 \\
4 & 1.100702 & 90.97249 & 1.944591 & 7.048275 & 0.034648 \\
5 & 1.212359 & 90.58817 & 2.017182 & 7.361282 & 0.033367 \\
6 & 1.313124 & 90.17610 & 2.123546 & 7.663952 & 0.036407 \\
7 & 1.407072 & 89.75015 & 2.220251 & 7.992356 & 0.037240 \\
8 & 1.494645 & 89.46740 & 2.294008 & 8.199456 & 0.039138 \\
9 & 1.577672 & 89.25287 & 2.344818 & 8.362399 & 0.039909 \\
10 & 1.656435 & 89.07622 & 2.388716 & 8.494262 & 0.040797 \\
\hline \hline
\end{tabular}

Untuk penjelasan Tabel 7. bagian Variance Decomposition of D (INFLASI), menunjukkan kontribusi yang jadi pada variabel inflasi, dimana pada periode ke-1 inflasi berkontribusi $100 \%$ pada inflasi sendiri, sementara variabel kurs, jumlah uang beredar dan BI rate belum memberikan kontribusi sama sekali karena bernilai nol. Pada periode ke-2, inflasi periode sebelumnya memberikan kontribusi sebesar 97,85\% variabel inflasi saat ini, kurs memberikan kontribusi sebesar 0,27 \%, jumlah uang beredar memberikan kontribusi sebesar $1,85 \%$ dan Bi rate sebesar 0,0046\%. Hingga pada periode ke-10 inflasi periode sebelumnya memberikan kontribusi sebesar $89,07 \%$ pada inflasi saat ini, sementara kurs dan jumlah uang beredar serta BI rate masing-masing memberikan kontribusi sebesar $2,38 \%, 8,49 \%$ dan $0,04 \%$.

Tabel 8. Variance Decomposition of D (KURS)

\begin{tabular}{cccccc} 
Period & S.E. & D(INFLASI) & D(KURS) & D(JUB) & D(BIRATE) \\
\hline \hline 1 & 227.9423 & 0.349532 & 99.65047 & 0.000000 & 0.000000 \\
2 & 266.2715 & 2.593336 & 91.29496 & 5.768082 & 0.343623 \\
3 & 312.6163 & 5.745916 & 81.68367 & 12.32111 & 0.249304 \\
4 & 346.0930 & 6.848483 & 79.63423 & 13.29627 & 0.221017 \\
5 & 378.6877 & 7.266344 & 78.67959 & 13.85639 & 0.197675 \\
6 & 408.0827 & 7.710651 & 77.59348 & 14.51137 & 0.184499 \\
7 & 435.7811 & 8.079155 & 76.66108 & 15.08809 & 0.171666 \\
8 & 461.6520 & 8.355564 & 76.01116 & 15.47114 & 0.162135 \\
9 & 486.2096 & 8.565434 & 75.50576 & 15.77418 & 0.154623 \\
10 & 509.5674 & 8.742412 & 75.07937 & 16.02975 & 0.148466 \\
\hline \hline
\end{tabular}

Hasil analisis VD pada Tabel 8. dapat diketahui bahwa pada periode ke-1 inflasi memberikan kontribusi sebesar $0,34 \%$ pada terbentuknya kurs, sementara kurs sendiri memberikan kontribusi sebesar $99,65 \%$, jumlah uang beredar dan BI rate tidak memberikan kontribusi terhadap terbentuknya kurs. Perbedaan terjadi pada periode ke- 2 dimana inflasi memberikan kontribusi sebesar2,59\%, sementara kurs sendiri memberikan kontribusi sebesar 91,29\%, jumlah uang bereda dan BI rate masing-masing memberikan kontribusi sebesar $5,76 \%$ dan $0,34 \%$. Kontribusi antar variabel terus terjadi, sampai pada periode ke10 dimana inflasi memberikan kontribusi sebesar 8,74\%, sementara kurs sendiri 
memberikan kontribusi sebesar 75,07\%, jumlah uang beredar dan BI rate masing-masing memberikan kontribusi sebesar 16,02\% dan 0,14\%.

Tabel 9. Variance Decomposition of D (JUB)

\begin{tabular}{cccccc} 
Period & S.E. & D(INFLASI) & D(KURS) & D(JUB) & D(BIRATE) \\
\hline \hline 1 & 7110620. & 5.830245 & 0.065857 & 94.10390 & 0.000000 \\
2 & 7470181. & 12.20080 & 1.081870 & 85.63708 & 1.080248 \\
3 & 8536018. & 23.56062 & 5.345006 & 70.25516 & 0.839206 \\
4 & 9106923. & 27.87861 & 5.949261 & 65.29759 & 0.874532 \\
5 & 9783792. & 30.87608 & 6.453175 & 61.88827 & 0.782477 \\
6 & 10325554 & 33.56941 & 6.929931 & 58.72338 & 0.777275 \\
7 & 10891790 & 35.83774 & 7.409317 & 56.02262 & 0.730329 \\
8 & 11405309 & 37.63469 & 7.741722 & 53.91356 & 0.710032 \\
9 & 11908726 & 39.11491 & 8.023397 & 52.17730 & 0.684384 \\
10 & 12384520 & 40.38754 & 8.263080 & 50.68189 & 0.667492 \\
\hline \hline
\end{tabular}

Hasil analisis VD pada Tabel 9. dapat diketahui bahwa pada periode ke-1 inflasi memberikan kontribusi sebesar 5,83\% pada terbentuknya jumlah uang beredar, sementara kurs memberikan kontribusi sebesar $0,06 \%$, jumlah uang beredar sendiri memberikan kontribusi sebesar $94,10 \%$ dan BI rate tidak memberikan kontribusi terhadap terbentuknya kurs. Perbedaan terjadi pada periode ke-2 dimana inflasi memberikan kontribusi sebesar $12,20 \%$, sementara kurs memberikan kontribusi sebesar 1,08\%, jumlah uang bereda dan $B I$ rate masing-masing memberikan kontribusi sebesar $85,63 \%$ dan $1,08 \%$. Sampai pada periode ke-10 dimana inflasi memberikan kontribusi sebesar 40,38\%, sementara kurs memberikan kontribusi sebesar 8,26\%, jumlah uang beredar dan BI rate masing-masing memberikan kontribusi sebesar 50,68\% dan 0,66\% pada terbentuknya jumlah uang beredar.

Tabel 10. Variance Decomposition of D (BIRATE)

\begin{tabular}{cccccc} 
Period & S.E. & D(INFLASI) & D(KURS) & D(JUB) & D(BIRATE) \\
\hline \hline 1 & 0.190091 & 0.816564 & 0.201377 & 0.356839 & 98.62522 \\
2 & 0.223855 & 4.208399 & 0.301884 & 0.924844 & 94.56487 \\
3 & 0.268031 & 3.986393 & 0.387982 & 0.645214 & 94.98041 \\
4 & 0.299233 & 4.620269 & 0.419512 & 0.840784 & 94.11943 \\
5 & 0.330225 & 4.602625 & 0.412174 & 0.741725 & 94.24348 \\
6 & 0.357234 & 4.806616 & 0.432578 & 0.755207 & 94.00560 \\
7 & 0.382948 & 4.862698 & 0.435681 & 0.714817 & 93.98680 \\
8 & 0.406731 & 4.950465 & 0.444045 & 0.710283 & 93.89521 \\
9 & 0.429353 & 4.995927 & 0.446713 & 0.693172 & 93.86419 \\
10 & 0.450762 & 5.045591 & 0.451192 & 0.685709 & 93.81751 \\
\hline \hline
\end{tabular}$==$

Hasil analisis VD pada Tabel 10. dapat diketahui bahwa pada periode ke-1 inflasi memberikan kontribusi sebesar $0,81 \%$ pada terbentuknya BI rate, sementara kurs memberikan kontribusi sebesar 0,20, jumlah uang beredar sendiri memberikan kontribusi sebesar 0,35\% dan BI rate sendiri memberikan kontribusi sebesar 98,62. Perubahan terjadi pada periode ke-2 dimana inflasi memberikan kontribusi sebesar 4,20\%, sementara kurs 
memberikan kontribusi sebesar 0,30\%, jumlah uang bereda memberikan kontribusi sebesar 0,92\% sementara BI rate sendiri berkontribusi sebesar $94,56 \%$. Sampai pada periode ke10 dimana inflasi memberikan kontribusi sebesar 5,04\%, sementara kurs memberikan kontribusi sebesar $0,45 \%$, jumlah uang beredar sebesar $0,68 \%$ dan BI rate sendiri berkontribusi sebesar $93,81 \%$.

\section{KESIMPULAN}

Penelitian terkait variabel makro ekonomi yang terdiri dari inflasi, kurs, jumlah uang beredar serta BI rate untuk periode pengamatan antara tahun 2010 sampai dengan 2019 menunjukkan hasil yang beragam. Berdasarkan hasil uji kausalitas didapati bahwa inflasi dan $B I$ rate tidak terdapat hubungan kausalitas. Begitu pula variabel jumlah uang beredar tidak saling mempengaruhi $B I$ rate. Untuk variabel kurs juga tidak saling berpengaruh terhadap variabel $B I$ rate. Hasil uji kausalitas juga menunjukkan bahwa jumlah uang beredar tidak terdapat hubungan kausalitas terhadap inflasi, Sementara variabel kurs saling berpengaruh terhadap inflasi. kurs tidak saling berpengaruh terhadap variabel jumlah uang yang beredar.

Penjelasan hasil estimasi model VECM secara umum menunjukkan adanya hubungan jangka panjang dan hubungan jangka pendek dari masing-masing variabel. Analisis IRF menunjukkan terdapat respon atas goncangan yang terjadi pada variabel itu sendiri maupun variabel yang lain. Sementara analisis VD menunjukkan bahwa terdapat peran kontribusi yang besar dari varibel itu sendiri serta sebagian yang lain kontribusi pembentuknya berasal dari ketiga variabel yang lain.

\section{DAFTAR PUSTAKA}

Adisetiawan, R. (2014). Keseimbangan Jangka Panjang antara Variabel Makro Ekonomi dengan Indeks Harga Saham. Trikonomika Journal, 10(2), 72-84.

Andiantyo, P., Sihombing, P., dan Kusumastuti, S. Y. (2018). Pergerakan Indeks Harga Saham Sektor Pertanian di Bursa Efek Indonesia. Prosiding Seminar Nasional Cendekiawan, 1137-1148.

Desvina, A. P., dan Lubis, P. S. (2019). Pendekatan VECM Untuk Menganalisis Hubungan IHSG, BI Rate, Kurs (USD/IDR), dan Jumlah Uang Yang Beredar (M2). Jurnal Sains Matematika dan Statistika: Jurnal Hasil Penelitian Matematika, Statistika, dan Aplikasinya, 5(1).

Ekananda, M. (2016). Analisis Ekonometrika Dan Analisis Time Series. Mitra Wacana Media.

Hendajany, N. (2016). Tingkat Inflasi, Suku Bunga Bank Indonesia, Jumlah Uang Beredar dan Kurs. Eko-Regional: Jurnal Pembangunan Ekonomi Wilayah, 10(1).

Janah, I. U., dan Pujiati, A. (2018). Analisis Mekanisme Transmisi Kebijakan Moneter Jalur Ekspektasi dalam Mempengaruhi Inflasi di Indonesia. Economics Development Analysis Journal, 7(4), 384-394.

Kristanto, M. E., dan Idris, I. (2016). Analisis Pengaruh Inflasi, Kurs, dan Suku Bunga Terhadap Pergerakan Bersama Return Saham IHSG dan Volume Perdagangan 
Periode Januari 2006-Desember 2015. Diponegoro Journal of Management, 5(3), $792-806$.

Lubis, I. (2017). Pengaruh Makro Ekonomi Terhadap Pasar Saham Liquid Di Indonesia. Jurnal Mandiri: Ilmu Pengetahuan, Seni, dan Teknologi, 1(1), 56-67.

Luwihadi, N. L. G. A., dan Arka, S. (2017). Determinan Jumlah Uang Beredar dan Tingkat Inflasi di Indonesia Periode 1984-2014. E-Jurnal Ekonomi Pembangunan Universitas Udayana, 6(4), 165365.

Mankiw, N. G. (2007). Makroekonomi edisi keenam. Jakarta: Erlangga.

Najiatun, M. S., Rahman, M., dan Herianingrum, S. (2019). Analisis Variabel Makroekonomi Terhadap NPF Perbankan Syariah di Indonesia. Jurnal Ekonomi, 24(3), 335-349.

Natsir, M. N. (2018). Analisis Empiris Efektivitas Mekanisme Transmisi Kebijakan Moneter di Indonesia Melalui Jalur Ekspektasi Inflasi Periode 1990: 2-2007: 1. EKUITAS (Jurnal Ekonomi dan Keuangan), 13(3), 288-307.

Nisa, N. K., dan Sukmana, R. (2017). Analisis Pengaruh Variabel-Variabel Makro Ekonomi Terhadap Jakarta Islamic Indeks (JII) Periode 2007-2015. Jurnal Ekonomi Syariah Teori dan Terapan, 4(6), 449.

Nofiatin, I. (2013). Hubungan Inflasi, Suku Bunga, Produk Domestik Bruto, Nilai Tukar, Jumlah Uang Beredar, dan Indeks Harga Saham Gabungan (IHSG) Periode 20052011. Jurnal Aplikasi Manajemen, 11(2), 215-222.

Noviantoro, R. (2017). Analisa Faktor Makro Ekonomi Yang Mempengaruhi Kinerja Bank Syariah Di Indonesia. Jurnal Ekonomi dan Bisnis Dharma Andalas, 19(2), 279.

Rasbin, R. (2016). Hubungan Kausal Dinamis Antar Variabel Makro Ekonomi Di Indonesia Dalam Kajian Krisis Ekonomi Sebagai Kejutan Eksternal. Kajian, 20(1), 31-45.

Ratih, I. S., Adinugroho, M., dan Herianingrum, S. (2019). Penerapan Vector Auto Regression (VAR) Pada Jakarta Islamic Index dan Variabel Makro Ekonomi. Jurnal Ekonomi, 24(3), 368-382.

Salvatore, D. (2014). Ekonomi Internasional (Cetakan Pertama). Jakarta Selatan: Salemba Empat.

Sukirno, S. (2004). Makroekonomi teori pengantar. Jakarta: PT raja Grafindo persada.

Sulistiana, I. (2017). Model Vector Auto Regression (VAR) and Vector Error Correction Model (VECM) Approach for Inflation Relations Analysis, Gross Regional Domestic Product (GDP), World Tin Price, Bi Rate and Rupiah Exchange Rate. Integrated Journal of Business and Economics, 1(2), 17-32.

Sunariyah. (2011). Pengantar Pengetahuan Pasar Modal (6 ed.). AMP YKPN.

Triyono, D., Indarto, I., dan Santoso, A. (2016). Analisis Pengaruh Indeks Harga Saham Asing dan Variabel Makroekonomi Indonesia Terhadap Indeks Harga Saham Gabungan (IHSG) Di Bursa Efek Indonesia (Periode Januari 2013-Agustus 2015). Jurnal Riset Ekonomi dan Bisnis, 9(3), 20-39.

Viska, V. Y., dan Yusra, I. (2019). Pengaruh Tingkat Inflasi, Suku Bunga Dan Nilai Kurs Dollar As Terhadap Indeks Harga Saham Gabungan Pada Bursa Efek Indonesia.

Widokartiko, B., Achsani, N. A., dan Beik, I. S. (2016). Dampak kinerja internal dan kondisi makro ekonomi terhadap profitabilitas pada perbankan. Jurnal Aplikasi Bisnis dan Manajemen (JABM), 2(2), 161. 
Zaimsyah, A. M., Ayun, A. A., Rofi'ah, K., dan Herianingrum, S. (2020). Pengaruh Variabel Makroekonomi Terhadap Index Harga Saham Syariah. Jurnal Ekonomi, 25(1), 1-17. 